Available online on 15.06.2020 at http://jddtonline.info
Open Access to Pharmaceutical and Medical Research
(c) 2011-18, publisher and licensee JDDT, This is an Open Access article which permits
unrestricted non-commercial use, provided the original work is properly cited

Open $\odot$ Access

Research Article

\title{
The Influence of Green Tea Infusion (Camellia sinensis) on Renal Histopathological Overview of Male White Rats (Rattus Norvegicus) Sprague Dawley Strain Induced by Ethanol
}

\author{
Muhartono*, Katya Rizqita Fitriana \\ Department of Pathology, Medical Faculty of Lampung University, Lampung, Indonesia
}

\begin{abstract}
Aims: This sudy aims to determine the effect infusion of green tea (Camellia sinensis) to the renal histopathology picture of male white rats (Rattus norvegicus) Sprague dawley strain ethanol-induced.

Methods: This study used 30 rats divided into 5 groups. The negative control (K-) was given distilled water $2 \mathrm{~mL} / \mathrm{day}$, the positive control (K+) was given ethanol $2 \mathrm{~mL} /$ day, the treatment group (P1, P2, P3) was given ethanol $2 \mathrm{~mL}$ and green tea infusion with respective doses of 0.375 , 0.75 and 1.5 grams orally for 14 days. Then the renal retrieval is done to be examined microscopically.

Results: The mean kidney damage score obtained was $\mathrm{K}-=0.36 ; \mathrm{K}+=3.24 ; \mathrm{P} 1=2.52 ; \mathrm{P} 2=2,4 ;$ and $\mathrm{P} 3=2.2$. Data analysis with One Way Anova Test and continued with Pos Hoc and found significant differences in K- to K+, P1, P2, P3; K+ is significant to K-, P1, P2, P3; and P1, P2, P3 are significant to $\mathrm{K}-\& \mathrm{~K}+$.
\end{abstract}

Conclusion: There is an effect of infusion of green tea (Camellia sinensis) on the renal histopathological picture of male white rats (Rattus norvegicus) ethanol-induced Sprague dawley strain.

Keywords: alcohol, antioxidant, ethanol, green tea, renal histopathology

Article Info: Received 24 March 2020; Review Completed 28 May 2020; Accepted 03 June 2020; Available online 15 June 2020

\section{Cite this article as:}

Muhartono, Fitriana KR, The Influence of Green Tea Infusion (Camellia sinensis) on Renal Histopathological Overview of Male White Rats (Rattus norvegicus) Sprague Dawley Strain Induced by Ethanol, Journal of Drug Delivery and Therapeutics. 2020; 10(3-s):111-115 http://dx.doi.org/10.22270/jddt.v10i3-s.4101

*Address for Correspondence:

Muhartono, Department of Pathology, Medical Faculty of Lampung University, Lamp ung, Indonesia

\section{INTRODUCTION}

Alcohol is a fermented beverage, where it does the breakdown of simple sugars into alcohol, carbohydrates and water. ${ }^{1}$ Ethyl alcohol or ethanol is the content of alcoholic beverages made through the fermentation process of honey, sugar, fruit extract or sweet potatoes. ${ }^{2}$

Deaths due to alcohol consumption in the world reached 3,3 milion people ${ }^{3}$. The prevalence of the population in Indonesia aged 15 years and over drinking alcohol in one month is $4.9 \%$ for men, while $0.3 \%$ for women and about $2.5 \%$ for both. This requires long-term comprehensive countermeasures. ${ }^{4}$ Alcohol consumption in Lampung province during the last 12 months was around $2.2 \%$ and $1.4 \%$ in the last 1 month. ${ }^{5}$ The proportion of behaviour in 2018 of the consumption of alcoholic drinks in the last 1 month in the population aged $\geq 10$ year-old in Lampung province was $1.8 \%{ }^{6}$. The highest percentation of the population of Lampung province that consumed the most alcohol in the last 12 months was in Tulang Bawang district with percentage $3.6 \%$ and in the last 1 month in South Lampung district with percentage $2 \% .^{5}$

Alcohol that is drunk is metabolized from ethanol to acetate can be done by CYP2E1 especially if the ethanol concentration is high and the activity is triggered. CYP2E1 is triggered by chronic alcohol consumption; this can activate certain toxins such as CCL4. Metabolism through CYP2E1 also cause an increase in NADP+, this limits the availability of NADPH for regeneration of reduced glutathione so that there is an increase in oxidatif stress. ${ }^{7}$

Ethanol induction in the kidneys causes hyperacetylation of proteins that interfere with some functions of the mitochondria. ${ }^{13}$ In the research it was found that there was a reduction in Glutathion (GSH) levels that occured after 12 weeks of ethanol exposure. GSH has the function to coordinate the process of antioxidant action in the body. The catalase serves to catalyze the release of hydrogen peroxide, 
an increase in the activity of the catalase enzyme at the beginning of exposure, but in the end the activity of catalase enzyme decreases. ${ }^{14}$

After giving ethanol, ethanol and its metabolite pass through the kidneys to be excreted into the urin. The content of ethanol in the urin is higher than blood and liver. Large amounts of ethanol can have damaging effects on the kidneys. Structural and functional abnormalities of the kidneys are reported with increasing frequency of fetal alcohol syndrome. In animals that consume alcohol also found a decrease in kidneys function, interstitial edema and renal hypertrophy. ${ }^{8}$

Green tea or Camellia sinesis is a bush family member of theaceae in the wild which can reach 10-15 meters of height, while in the cultivation is only 0.6-1.5 meters of height. Camellia sinesis has green leaves with length $5-30 \mathrm{~cm}$ and width about $4 \mathrm{~cm}$, the stem is short, and jagged at the edges. Flowers on Camellia sinesis are white, fragrant and have diameter about 2,5-4 cm. ${ }^{9}$

Tea is reported has around 4000 bioactive compounds which one-third part is contributed by polyphenols. Polyphenols are benzene rings bound to several hydroxyl groups. Polyphenols contained in tea are mostly flavonoids derived from secondary plant metabolites which are derived from condensation of cinnamic acid to the three malonyl-KoA groups. The main flavonoid in green tea is tea catechins which are divided into: Epicatechin Gallate (ECG), Epicatechin (EC), Epigallocatechin (EGC), Epigallocatechin Galleate (EGCG). Catechins are colorless compounds and when dissolved in water give a bitter taste to tea infusions. Taste, aroma and color of tea are regulated in catechins. If there is a decrease in catechins, there will be an increase in the quality of aroma of the tea. ${ }^{10}$

Green tea can increase non-enzymatic antioxidants such as GSH, vitamin $\mathrm{C}$, vitamin $\mathrm{E}$, vitamin $\mathrm{A}$ and b-carotene which can decrease due to age and also due to ethanol intoxination (Elsayed, 2006). Green tea can inhibit redox transcription factors, inhibit pro-oxidant enzymes (lipooxygenase, cyclooxygenase, xanthine oxidase) and induction of antioxidant enzymes, such as glutathione-S-transferase and superoxide dismutase. ${ }^{12}$

Based on the description, it is expected that giving green tea infusion (Camellia sinensis) can be used to reduce free radicals derived from the effects of ethanol consumption, so it can reduce the damage of white rat renal induced by ethanol.

\section{MATERIAL AND METHOD}

This research was experimental research with posttest only controlled group design research design. This research was conducted for 14 days in October to November 2019 at Animal House Faculty of Medicine Lampung University and Histology and Anatomy Pathology Laboratory of Faculty of Medicine Lampung University.

The population in this research were white rats which were categorized in inclusion and exclusion criteria. Inclusion criteria: white rats (Rattus norvegicus) Sprague dawley strain, aged 8-12 weeks, weight 200-300 grams, and male. Exclusion criteria: rats that died during the research and treatment. The research sample was calculated by Frederer formula and divided into 5 groups, obtained the required samples were 25 . To avoid drop out 30 rats were needed for the whole sample which would divided into 5 groups.

The ethanol and green tea infusion were given for 14 days. After the experimental animal came, adaptation was carried out for 7 days. Then the grouping of experimental animal was carried out by randomization technique using a group division application and obtained 5 groups with 6 rats in each group. The group incuded negative controls given distilled water $2 \mathrm{~mL} /$ day, positive control group $(\mathrm{K}+)$ given ethanol $2 \mathrm{~mL} /$ day, trial group (P1, P2, P3) given ethanol 2 $\mathrm{mL} /$ day and consecutive 0.375 gram/day, 0.75 gram/day, and 1.5 gram/day. Renal histopathological overview seen from a light microscope with $400 x$ magnification in five fields of view and seen the damage which occured in glomerular and tubular. The measuring scale used a glomerular damage score including, $0=$ normal, $1=$ infiltration of inflammation cell, 2=spatium bowman edema, $3=$ necrosis and tubular damage score, such as $0=$ normal, $1=$ infiltration of inflammatory cell, $2=$ swelling of tubular epithelium, $3=$ necrosis

Data analysis with Shapiro-Wilk normality test $(\mathrm{p}>0.05)$ and Levene homogeneity test $(\mathrm{p}>0.05)$ then continued with One Way Anova Parametic Test $(\mathrm{p}<0.05)$ and continued with Post Hoc Analysis $(\mathrm{p}<0.05)$. This research was approved by The Ethics Research and Health Committee of the Faculty of Medicine Lampung University number 3912/UN26.18/PP.05.02.00/2019.

\section{RESULTS}

In this research, the number of samples used were 30 white male rats (Rattus norvegicus) Sprague dawley strain aged 812 weeks, weight 200-300 gram, and divided into 5 groups, negative control (K-), positive control $(\mathrm{K}+)$, treatment group 1 (P1), treatment group 2 (P2), and treatment group 3 (P3). Before conducting the study, the rats were adapted for 7 days. During 14 days of treatment, obtained 1 rat subject died in positive control. The following was renal histopathological overview of rats in each group of experiments. 

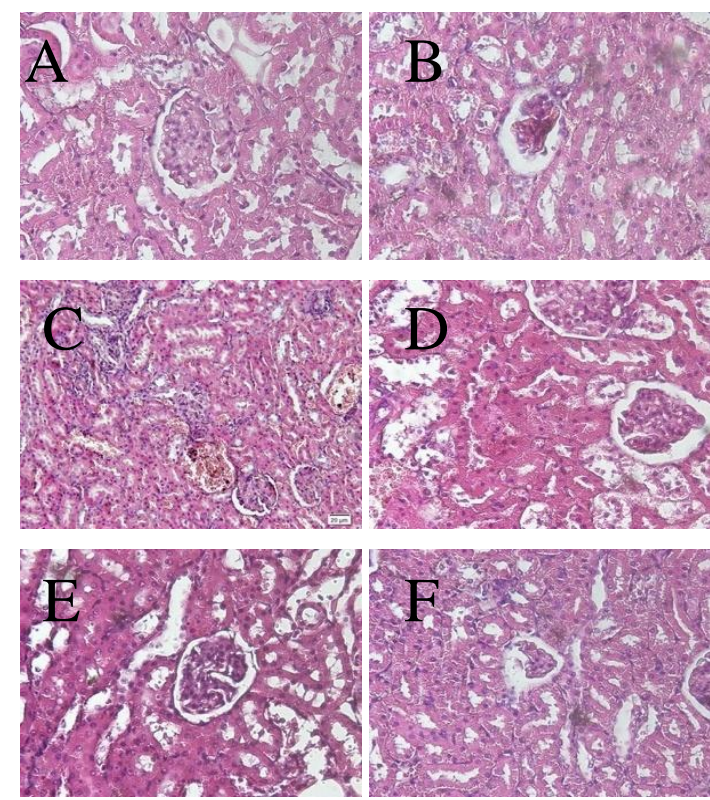

Picture 1. The Renal Histpathological Overview (400x).

Exp: A: K-, B: K+, C: K+, D: P1, E: P2, F: P3

Negative control group (K-) which given distilled water $2 \mathrm{~mL}$ per day obtained histopathological overview of glomerular cells and tubular was normal. No infiltration of inflammatory cells, congestion and necrosis. There was a little swelling in the tubular and spatium bowman.

Positive Control Group (K+) was rats group which given ethanol $2 \mathrm{~mL}$ per day. In histopathology overview obtained swelling in the kidney tubular indicated by the waning color of cell nucleus and seen swelling in cytoplasm. In the glomerular, spatium bowman edema and inflammation cells were found. Congestion was seen.

Treatment Group 1 (P1) was a group which given ethanol 2 $\mathrm{mL}$ and green tea infusion 0.375 gram per day. In renal histopathological overview, there was swelling in the cytoplasm of the kidney tubular. Still found a widening of the spatium bowman, altough not as severe as on $\mathrm{K}+$.

Treatment Group 2 (P2) was a group which given ethanol 2 $\mathrm{mL}$ and green tea infusion 0.75 gram per day. In renal histopathological overview still found swelling in tubular and spatium bowman edema in glomerular.

Treatment Group 3 (P3) was a group which given ethanol 2 $\mathrm{mL}$ and green tea infusion 1.5 gram per day. In histopathological overview there was still obtained swelling spatium bowman edema in some glomerular.

The average results of kidney histopathological analysis showed the score of kidney damage at negative control was 0.36; positive control was 3.24; treatment group 1 was 2.52; treatment group 2 was 2.52; and treatment group 3 was 2.4 . The highest average score of the kidney damage on positive control was 3.24 which given ethanol $2 \mathrm{~mL}$ per day and the lowest average score of the kidney damage on negative control was 0.36 which given distilled water $2 \mathrm{~mL}$ per day. Based on the average assessment, it was found that there was a decrease in the average of kidney damage in rats that given tiered dosage infusion of green tea compared by the kidney damage score only given ethanol.
Table 1: Shapiro-Wilk Normality Test

\begin{tabular}{cc}
\hline Treatment Groups & Shapiro-Wilk Sig. \\
\hline Negative Control (K-) & 0.377 \\
Positive Control (K+) & 0.490 \\
Treatment 1 (P1) & 0.758 \\
Treatment 2 (P2) & 0.111 \\
Treatment 3 (P3) & 0.685
\end{tabular}

Based on table 1. Data analysis normality test was conducted with shapiro-wilk test because of the sample was less than or equal 50. In shapiro-wilk test, it was found that $\mathrm{K}-, \mathrm{K}+, \mathrm{P} 1$, P2, and P3 were $>0.05(p>0.05)$ then it can be concluded that the data was normally distributed.

Table 2: Homogeneity Test

\begin{tabular}{cc}
\hline Levene Statistic & Sig. \\
\hline 0.101 & 0.981
\end{tabular}

Based on table 2. After conducting normality test, homogeneity test was conducted to find out whether the data is homogeneous or not, it was found that the significance value was $p=0.981(p>0.05)$ it can be concluded that the data was homogeneous.

Table 3: One Way Anova Hypothesis Test

\begin{tabular}{llll}
\hline & Mean Square & F & Sig. \\
\hline Between Groups & 5.760 & 38.919 & .000 \\
Within Groups & 0.148 & & \\
Total & & & \\
\hline
\end{tabular}

Based on table 3. After the data was normally distributed and homogeneous, the research was continued with hypothesis test using One Way Anova and it was found 0,00 $(\mathrm{p}<0,05)$ it means that the hypothesis was accepted. 
Table 4: Post Hoc LSD Test

\begin{tabular}{llllll}
\hline Groups & K- & K+ & P1 & P2 & P3 \\
\hline K- & - & $0.000^{*}$ & $0.000^{*}$ & $0.000^{*}$ & $0.000^{*}$ \\
K+ & $0.000^{*}$ & - & $0.008^{*}$ & $0.003^{*}$ & $0.001^{*}$ \\
P1 & $0.008^{*}$ & $0.008^{*}$ & - & 0.627 & 0.336 \\
P2 & $0.000^{*}$ & $0.003^{*}$ & 0.627 & - & 0.627 \\
P3 & $0.000^{*}$ & $0.001^{*}$ & 0.336 & 0.627 & - \\
\hline
\end{tabular}

Exp: ${ }^{*} \mathrm{p} \leq 0.05=$ significant

Based on table 4. The results of analysis Post Hoc obtained the results of negative control group (K-) were significant for $\mathrm{K}+, \mathrm{P} 1, \mathrm{P} 2$, and $\mathrm{P} 3$. Positive control group (K+) obtained the results that significant for K-, P1, P2, and P3. Group P1, P2, and $\mathrm{P} 3$ were significant for $\mathrm{K}-$ and $\mathrm{K}+$. It called significant because the value of $p$ was $\leq 0.05$. Meanwhile, the value of $p$ between Group P1 and P2 was 0.627; Group P1 and P3 was 0.336; Group P2 and P3 was 0.627; it can concluded that the groups did not have significant difference because $p>0.05$.

\section{DISCUSSION}

In the microscopic results that have been observed it was obtained negative control group which given distilled water $2 \mathrm{~mL}$ per day obtained the average of kidney damage was 0.36 . Changes in the renal histopathological overview can be caused by several things, such as stress. Stress due to chronic restraint can cause increased lipid peroxidation in the kidneys. Lipid peroxidation is oxidative degenerative polyunsaturated fat which causes disorder of membrane structure and function. This can increase the cytosolic hormone that can cause injury to cells, such as kidneys. 15

In positive control group (K+) and treatment group (P1, P2, P3) it was obtained that there were spatium bowman edema, tubular edema, infiltration of inflammation cells, and congestion.

Microscopic overview of swelling of tubular epithelium with granular cytoplasm caused by the shifting of extracellular water into cells. ${ }^{16}$ This mitochondria enlargement results in decreased oxygen consumption, ATP synthesis and ROS formation in cells. It is known that mitochondrial enlargement is a cell adaptive process when oxidative stress occurs. 17

Permeability disorder in the tubular cell membrane causes sodium retention. The disorder was the result of damage of free radical cell membranes associated with lipids and cause lipid peroxidation reactions and oxidative stress. The cell membrance has function for regulation. The disorder in cell membrane causes an increase in sodium in cells which result in the accumulation of a certain amount of water into cell by the osmosis process. This can cause water accumulation in cells which causes edema in tubular epithelial cells. ${ }^{18}$

The widening of the spatium bowman is expected to reduce and maintain normal capillary hydrostatic pressure so as to prevent glomerular damage. The increase in hydrostatic pressure caused by an increase in blood pressure in the glomerular capillaries. Spatium bowman edema is one of the protective effects against glomerular injury due to high pressure. ${ }^{19}$

The inflammatory process also plays an important role in nephrotoxity due to oxidative stress. The inflammation process will increase production of proinflammatory cytokines, such as TNF $\alpha$ and IL-1 $\beta$, which then will release macrophages. ${ }^{20}$ In the research of nefrectosisitas which induced by carboplatin, it was obtained the increase of TNF $\alpha$ and giving L-karnitin would reduce TNF $\alpha$ and free oxygen radical levels. ${ }^{21}$

Congestion overview in $\mathrm{K}+$ was a passive process caused by the disorder in venous tissue flow. Congestion can occur as systemically, as in heart failure or can occur locally, such as the presence of congestion in certain veins. In chronic congestion, inadequate tissue perfusion and persistent hypoxia can cause death from parenchymal tissue cells and secondary tissue fibrosis, and increased intravascular pressure that can cause edema or capillary rupture that can cause local bleeding. ${ }^{22}$

Giving green tea infusion (Camellia sinensis) that functions as an exogenous antioxidant has an effect on oxidative stress due to ethanol induction. This can be proven from the average damage score where in the $\mathrm{K}+$ group which given ethanol $2 \mathrm{~mL}$ for 14 days had a higher damage (3.24) than the treatment group which given green tea infusion with multilevel dosage (P1, P2, and P3) successively were 2.52; 2.40; and 2.20 that showed the influence of giving green tea infusion on renal histopathological overview of white male rats (Rattus norvegicus) Sprague Dawley strain induced by ethanol for 14 days.

From the results of data analysis conducted normality data test using Shapiro-Wilk test ( $\mathrm{p}>0.05$ ) it was found that the data was normally distributed, then continued with homogeneity test $(p>0.05)$ and it was obtained homogeneous data, then hypothesis test was conducted using One Way Anova and it can be conclude that the hypothesis was accepted, and the last Post Hoc test was conducted to see whether the data was significant or not. In the results of Post Hoc test, it was found that the data was significant for $\mathrm{K}-$ and $\mathrm{K}+, \mathrm{P} 1, \mathrm{P} 2$, and $\mathrm{P} 3$; $\mathrm{K}+$ significant for $\mathrm{K}$-, P1, P2 and P3; and P1, P2, P3 significant for $\mathrm{K}-$ and $\mathrm{K}+$. It was obtained non-significant data between P1-P2, P1-P3, and P2P3 which means giving dosage of green tea infusion in P2 and P3 was gave almost the same effect with P1.

\section{CONCLUSION}

According to the results of the research, it can conclude that obtained the effect of giving ethanol on renal histopathological overview of white rats (Rattus norvegicus) Sprague dawley strain and the effect of giving green tea infusion (Camellia sinensis) on renal histopathological overview of white rats (Rattus norvegicus) Sprague dawley strain induced by ethanol.

\section{Acknowledgement}

Authors are thankfull to Histology and Pathology Laboratory, Medical Faculty of Lampung University for providing facilities to carry out our research.

\section{REFERENCES}

1. Putra A, "Pengaruh Alkohol Terhadap Kesehatan" Prosiding Semnas FMIPA Undiksha, 2012; 1(3):17-24.

2. Kementerian Kesehatan RI. Bahaya minuman keras bagi kesehatan. Jakarta: Kementerian Kesehatan RI; 2014.

3. WHO. Global status report on alcohol and health 2014. Geneva: WHO; 2014.

4. Suhardi, "Preferensi Peminum Alkohol di Indonesia Menurut Riskesdas 2007" Kemenkes, 2011; 39(4):156-64.

5. Departemen Kesehatan Republik Indonesia. Laporan riset kesehatan dasar riskesdas Provinsi Lampung tahun 2007. Jakarta: Departemen Kesehatan RI; 2007.

6. Kementrian Kesehatan RI. Laporan nasional RISKESDAS 2018. Jakarta: Lembaga Penerbit Badan Penelitian dan Pengembangan Kesehatan; 2019. 


\section{Muhartono et al}

7. Brunton L, Blumenthal D, Parker K, Buxton I. Goodman \& Gillman manual farmakologi dan terapi. California: McGraw-Hill; 2008.

8. Das SK, Vasudevan DM, "Alcohol Induce Effect of Kidney" Indian Journal of Clinical Biochemistry, 2008; 23(1):4-9.

9. Sinija VR, Mishra HN, "Green Tea: Health Benefits" Journal of Nutritional and Enviromental Medicine, 2008; 17(4):232-42.

10. Mahmood T, Akhtar N, Khan BA, "The Morphology, Characteristics, and Medicinal Properties Of Camellia Sinensis Tea" Journal of Medicinal Plants Research, 2010; 4(19):202833.

11. Elsayed ASI, "Green Tea Antioxidant Effects and Its Ameliorative Role Against Many Disease" International Journal of Applied Biology and Pharmaceutical Technology, 2016; 7(1):73-94.

12. Cabrera C, Artachi R, Gimenez R, "Beneficial Effects of Green Tea-A Review" Journal of the American Collage of Nutrition, 2006; 25(2):79-99.

13. Harris PS, Roy SR, Coughlan C, Orlicky DJ, Liang Y, Shearn CT, "Chronic Ethanol Consumption Induces Mitochondrial Protein Acetylation and Oxydative Stress in Kidney", Redox Biology, 2015; 6(2015):33-40.

14. Das SK, Vasudevan DM, "Alcohol-Induced Oxidative Stress" Life Science, 2007; 81(2007):177-87.

15. Jafari M, Salehi M, Zardooz H, Rostamkhani F, "Response of Liver Antioxidant Defense to Acute and Chronic Physical and Psycological Stresses in Male Rats" EXCLI J, 2014; 13:161-71.

16. Togatorop D, Pasiak TF, Wongkar D, Kaseke MM, "Gambaran Histologik Tikus Wistar yang Diberikan Jus Tomat Setelah
Journal of Drug Delivery \& Therapeutics. 2020; 10(3-s):111-115

Diinduksi dengan Monosodium Glutamat' Jurnal e-Biomedik, 2016; 4(2):1-8.

17. Manzo-Avalos S, Saavendra-Molina A, "Cellular and mithocondrial effects of alcohol consumption" Internationa Journal of Enviromental Research and Public Health, 2010; 7(12):4281-304.

18. Sethi HS, Menon V, "Toxic and Nutritional Optic Neuropathy" DOS Times, 2006; 11(8):367-369.

19. Juhryyah S. Gambaran histopatologi organ hati dan ginjal tikus pada intoksikasi akut inteksida (metofluthrin, D-Phenothrin, DAllethrin) dengan dosis bertingkat. Bogor: Institut Pertanian Bogor; 2008.

20. Tobar A, Ori Y, Benchetrit S, Milo G, Herman M, Zingerman B, "Proximal Tubular Hypertrophy and Enlarged Glomerular and Proximal Tubular Urinary Space in Obese Subjects with Proteinuria" PLos One, 2013; 8(9):1-915.

21. Kunak $\mathrm{CH}$, Ugan RA, Cadirci E, Karakus E, Polat B, Un $\mathrm{H}$ "Nephoprotective Potential of Carnitine Againts Glycerol and Contrast-Induced Kidney Injury in Rats Through Modulation of Oxidative Stress, Proinflammatory Cytokines, and Apoptosis" $\mathrm{Br}$ J Radiol, 2016; 89(1058):2014-724.

22. Arafa HMM, "Carnitine Deficiency Aggravates Carboplatin Nephropathy Through Deterioration of Energy Status, Oxidant/Anti-Oxidant Balance, and Inflammatory Endocoids" Toxicology, 2008; 254(1-2):51-60.

23. Kumar V, Abbas AK, Aster JC. 2013. Buku ajar patologi robbins. $9^{\text {th }}$ Eds. Jakarta: Elsevier; 2013. 